\title{
Teacher's Perception towards Headmaster Leadership in Linus Management for Elementary School in Debak Zone, Betong, Sarawak
}

\author{
Mohd Jasmy Abd Rahman, Anjau Anak Jimbat, Mohd Radzani Abd Razak, \\ Md. Yusoff Daud, Nur Kamariah Ensimau
}

Faculty of Education, The National University of Malaysia, Bangi, Malaysia

Email:mjas@ukm.edu.my

How to cite this paper: Rahman, M. J. A., Jimbat, A. A., Razak, M. R. A., Daud, Md. Y., \& Ensimau, N. K. (2019). Teacher's Perception towards Headmaster Leadership in Linus Management for Elementary School in Debak Zone, Betong, Sarawak. Creative Education, 10, 3142-3152.

https://doi.org/10.4236/ce.2019.1012238

Received: October 21, 2019

Accepted: November 26, 2019

Published: November 29, 2019

Copyright (c) 2019 by author(s) and Scientific Research Publishing Inc. This work is licensed under the Creative Commons Attribution International License (CC BY 4.0).

http://creativecommons.org/licenses/by/4.0/

\section{(c) (i) Open Access}

\begin{abstract}
The purpose of this study is to examine teachers' perceptions towards the leadership of the headmaster in LINUS management in primary school. The population consisted of primary school teachers included in "Zon Debak". The design of the study is qualitatively using survey methodology. The primary aim is to examine teachers' perceptions of headmaster leadership in LINUS management based on demographic characteristics such as gender, race, service duration, and school location. The respondents of this study are teachers working in primary school within "Zon Debak" where data are gathered using online questionnaires to identify teachers' perceptions of headmaster leadership in the management of LINUS. The 23rd version of SPSS (Statistical Package for Social Sciences) software is used to analyze all the data collected. This study analyzed the data descriptively, using percent and mean in the procedure of data analysis. The findings showed that there was no significant difference among teachers' perceptions of headmaster leadership in LINUS management based on demographic factors. Therefore, the collaboration among the Ministry of Education Malaysia, the State Education Department, the District Education Department, the teachers and the researchers are most welcomed in order to straighten the management and administration of the school.
\end{abstract}

\section{Keywords}

Teacher's Perception, Principal Leadership, LINUS Management, Primary School

\section{Introduction}

Leadership is defined as the process that moves a group of people toward a goal 
that is set by the impetus for fulfilling long-term goals. This scenario also involves the ability to influence and persuade people inside and outside the organization to work and assist in achieving the vision and mission of the organization (Alimuddin, 2010). The effectiveness of this leadership can be seen through the commitment the workers that make to their organization. Ryska (2002) states that leadership styles greatly influence the behavior of employees in performing their work. This statement is supported by Fiedler (1967) who states that a leader's leadership style is an attraction for employees to continue working towards achieving the vision and mission of an organization. Leadership gives a lot of insights depending on its importance and usefulness. The leader is like a master who saves his ship safely and carefully so that nothing bad happens to his crew. Likewise, the competence of leaders in school organizations who work together to ensure that all students are united and working together to achieve the school's goals that lead to good and positive outcomes to be an effective leader of the school. Headmaster should also be able to influence the entire school community under his leadership with positive and effective ways to achieve educational goals in schools as suggested in the transnational leadership style (Ibrahim et al., 2015).

According to Alias et al. (2018), among the element in leadership is that the headmaster should be capable to lead and mobilize the entire school towards attaining the vision and mission, with a clear school policy to achieve. Headmaster should also adopt appropriate style of leadership and build a strong working team which contributes towards knowledge development and advanced thinking culture in school community. In schools, the headmaster is the key leader in creating effective leadership as well as able to facilitate emotional competency skills towards better decision making (Harun et al., 2017). Not only that, as a leader, the headmaster must have charisma, good personality and the ability to lead, guide, plan and drive the students towards achieving the mission and vision of the organization.

The Ministry of Education, as stated in the PIPP, has stated that the appointment of a principal or a headmaster is based on the selection of the most qualified candidates and not solely on seniority. This clearly shows the importance of the role of principals and teachers in determining the success of a school. Given the importance of the headmaster in designing and determining the direction and success of a school, many authors have labeled the headmaster as "the one who decides the formation of a school" and "the one who determines the setting and direction of the school". The title shows that a great deal of recognition has been given to the community by the headteacher. There are many studies and writings that conclude that a great teacher is an important leader in developing a school (Edmonds, 1979).

\section{Problem Statement}

Leadership skills among headmaster is an unpredictable matter because headmaster has to deal with various parties such as the Ministry of Education 
Malaysia, the State Education Department, the Education Office, teachers, parents, students and the local community in many situations. Therefore the leadership of the headmaster is largely determined by the parties dealing with it. On the other hand, teachers can also determine and evaluate their teachers' leadership through their observations, observations and interpretations of their senses. Most teachers in schools have developed different perspectives in their perceptions of head teachers. Differences in perceptions of headmaster teachers are also influenced by demographic factors such as gender, race, duration of service and school location. This perception will determine the effectiveness of a headmaster's leadership in the management of LINUS in schools.

This study involved principals' leadership as there are many issues of implementation of LINUS that are raised each time verification of LINUS-related data is presented at the headmaster meetings and during a joint performance dialogue with the district or district head teachers. Among the issues raised such as the instrument being not reviewed, teaching and learning monitoring were not fully monitored and LINUS issues were not discussed at the meeting.

\section{Conceptual Frame}

Based on Figure 1, it is found that this study consists of two variables namely independent variable and dependent variable. The independent variables were the demographics of the headmistress consisting of gender, school location, and period of service of the headmaster. Next, the dependent variable is the level of headmaster leadership in LINUS management based on the Transformational Leadership Theory by Burns (1978) and Bass (1985).

\section{Research Objective}

The purpose of this study is to identify teachers' perceptions of the level of headmaster leadership in LINUS management at the primary school level in Betong which can contribute to the school's excellence in achieving the mission and vision of an organization.

\section{Literature Review}

Studies on educational leadership have shown that leaders play an important role in making a school successful and achieving high performance. As a result, the leadership of the headmaster has an impact on the teacher's self-motivation, self-development, morale and intellectual development.

In Malaysia, there is still lack research done to investigate the quality level of service among school teachers especially in Malaysia as reported by Aziz \& Mat (2017). This does not exclude headmaster since the leadership style of a teacher who eventually become headmaster, if it is not rightfully done, may cause negative impact which can affect school excellence especially in terms of teaching and learning effectiveness. As well as management aspects regarding effective teaching and learning which is important as it is the benchmark for student 


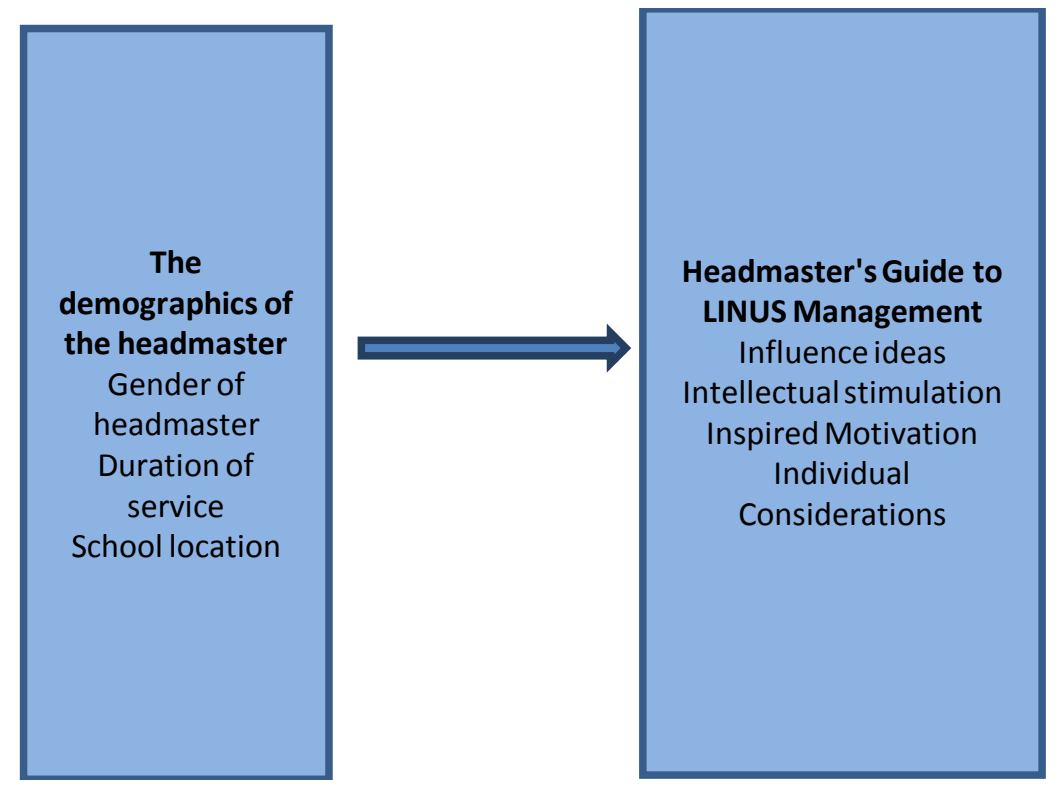

Figure 1. Theoretical Framework.

achievement. The changes that come from headmaster leadership in schools do not focus solely on technical agendas such as listing the duties and responsibilities of teachers that they need to perform in order to achieve good grades (Hamzah \& Shamsudin, 2017). Teacher leadership competence is a variable that can be manipulated to enhance management effectiveness and further enhance school excellence in school management especially in LINUS management.

The leadership style of the headmaster also influences the management of administrators in managing the organization's affairs. According to Ibrahim et al. (2015), the capability of the leaders in implementing advanced transformation to carry out the organizational functions usually gave a significant impact on individual outcome that relates to organizational commitment. Especially in the management of LINUS in their respective schools. A good headmaster can improve LINUS achievement in schools under the leadership of a leader committed to managing the organization. Leadership is also a process of persuading and influencing followers in most matters that involve the decision to make a change or the desire to remain in an organization (Cyril \& Ginndra, 2009).

The Education Policy Research and Planning Division data shows that the dropout rate for primary and secondary students in Malaysia in 2008 was 31, 939. Is taken seriously because students who have not mastered the basic skills of reading, writing and counting are at risk of falling apart and are having difficulty meeting the need for further education and careers (PIPP 2013-2025, 2007). The systematic leadership of principals can improve LINUS achievement in schools. This is because LINUS is a program that should be given full attention as it is one of the programs that has been introduced since 2010. LINUS and is also a government strategist in the National Key Result Area (NKRA). is to create a high literacy capacity for advanced literacy groups by 2020 (Khairuddin, 2011). 


\section{Methodology}

This study uses survey design. This review aims to examine teachers' perceptions of headmaster leadership in LINUS management. Data are collected using quantitative methods. This method was chosen because it gives a strong picture of the headmaster's leadership. Participants of this study were among several primary school teachers selected to conduct this study. All data will be analyzed using SPSS software. This study uses quantitative methods where the process of collecting and analyzing data is carried out according to the distributed questionnaire.

According to Noraini (2013), quantitative research is concerned with the objectives and data collection and assumes that every phenomenon that occurs is described by measuring the elements involved. Cresswell (2008) states that quantitative approaches are something to be studied. The researcher narrows down the scope of the question and measures the elements that can be administered to the participant, analyzes the data using statistics and performs the inquiry in an objective manner. The design of the study using survey and qualitative methods. The total teacher population of the ten schools was 143 teachers. The selection of respondents is by using a simple random sampling method. Determination of sample size is based on Krejcie \& Morgan's (1970) sampling method in the textbook Berawi (2017). According to the table of Krejcie and Morgan (1970), if $\mathrm{N}=140$, then $\mathrm{S}=103$ but only 100 people have sent feedback and these are the respondents in this study.

Based on Table 1, most respondent is women which is 60 people (60\%) out of the total 100 respondents and 40 of them are men (40\%). Bumiputera Sarawak/Sabah respondents made up the most respondent which is 44 participants (44\%). Followed by Malay respondent, 43 participants (43\%) and 13 Chinese respondent (13\%) and sadly no respondent from Indian. Next, for service duration, 14 respondents (14\%) have served in the period less than 5 years while 13 respondents (13\%) have served within 5 to 10 years. There are 32 respondents (32\%) who served minimum of 11 to 15 years while respondents who served from 16 to 20 years are up to 19 respondents (19\%) and respondent who served the longest, which is 20 years and above is 22 respondents (22\%). As for the data for school locations is $100 \%$ respondent who work in school in the suburb areas. As for academic achievement, 6 respondents (6\%) obtained minimum of SPM, STPM certificate holder only 1 respondent (1\%), Diploma holder is up to 4 respondents (4\%) while the rest of 86 respondents (86\%) holds Bachelor's degree and Master's degree only include of 3 people (3\%).

Table 2 shows the demographic of headmaster respondents in repective schools. 63 respondents (63\%) are men while 37 respondents (37\%) are women. Majority headmasters are Malay which is up to 61 respondents (61\%) followed by 7 Chinese headmasters (7\%) and 32 from Bumiputera Sarawak/Sabah (32\%). Next, for service duration, 19 respondents (19\%) have served less than 5 years followed by 18 respondents (18\%) who served at least 5 to 10 years. Then, 
Table 1. Demographic of respondents.

\begin{tabular}{|c|c|c|c|}
\hline Background & Respondent & Frequency & Percentage (\%) \\
\hline \multirow{3}{*}{ Gender } & Men & 40 & 40 \\
\hline & Women & 60 & 60 \\
\hline & Total & 100 & 100 \\
\hline \multirow{5}{*}{ Race } & Malay & 43 & 43 \\
\hline & Chinese & 13 & 13 \\
\hline & Indian & 0 & 0 \\
\hline & Bumiputera Sarawak/Sabah & 44 & 44 \\
\hline & Total & 100 & 100 \\
\hline \multirow{6}{*}{ Service Duration } & Less than 5 years & 14 & 14 \\
\hline & 5 to 10 years & 13 & 13 \\
\hline & 11 to 15 years & 32 & 32 \\
\hline & 16 to 20 years & 19 & 19 \\
\hline & 20 years and above & 22 & 22 \\
\hline & Total & 100 & 100 \\
\hline \multirow{4}{*}{ School Location } & City & 0 & 0 \\
\hline & Suburb & 100 & 100 \\
\hline & Rural & 0 & 0 \\
\hline & Total & 100 & 100 \\
\hline \multirow{6}{*}{ Academic Achievement } & SPM & 6 & 6 \\
\hline & STPM & 1 & 1 \\
\hline & Diploma & 4 & 4 \\
\hline & Bachelor's degree & 86 & 86 \\
\hline & Master's degree & 3 & 3 \\
\hline & Total & 100 & 100 \\
\hline
\end{tabular}

followed by 5 respondents (5\%) who served from 11 to 15 years, 16 respondents who served from 16 to 20 years the longest, more than 20 years is 42 respondents (42\%). Similarly, as for the data for school locations is $100 \%$ respondent who work in school in the suburb areas. As for academic achievement, there are 4 headmasters (4\%) with only SPM certificate and 2 headmasters with only STPM (2\%). Diploma holder only 1 (1\%) and the most respondent which is 92 respondents (92\%) have Bachelor's degree followed by one person (1\%) having a Master's degree.

This study is a quantitative study that uses the questionnaire form to obtain the required data according to the research purpose of the researcher. The questionnaire was based on a questionnaire from the Immigration and Quality Assurance Committee (JNJK) which was modified based on dimensions in Burns (1978) and Bass (1985). The questionnaire was divided into three sections 
Table 2. Headmaster demographic.

\begin{tabular}{|c|c|c|c|}
\hline Background & Respondent & Frequency & Percentage (\%) \\
\hline \multirow{3}{*}{ Gender } & Men & 63 & 63 \\
\hline & Women & 37 & 37 \\
\hline & Total & 100 & 100 \\
\hline \multirow{5}{*}{ Race } & Malay & 61 & 61 \\
\hline & Chinese & 7 & 7 \\
\hline & Indian & 0 & 0 \\
\hline & Bumiputera Sarawak/Sabah & 32 & 32 \\
\hline & Total & 100 & 100 \\
\hline \multirow{6}{*}{ Service Duration } & Less than 5 years & 14 & 14 \\
\hline & 5 to 10 years & 13 & 13 \\
\hline & 11 to 15 years & 32 & 32 \\
\hline & 16 to 20 years & 19 & 19 \\
\hline & 20 years and above & 22 & 22 \\
\hline & Total & 100 & 100 \\
\hline \multirow{4}{*}{ School Location } & City & 0 & 0 \\
\hline & Suburb & 100 & 100 \\
\hline & Rural & 0 & 0 \\
\hline & Total & 100 & 100 \\
\hline \multirow{6}{*}{$\begin{array}{c}\text { Academic } \\
\text { Achievement }\end{array}$} & SPM & 4 & 4 \\
\hline & STPM & 2 & 2 \\
\hline & Diploma & 1 & 1 \\
\hline & Bachelor's degree & 92 & 92 \\
\hline & Master's degree & 1 & 1 \\
\hline & Total & 100 & 100 \\
\hline
\end{tabular}

namely Part A, the respondent information, Part B regarding respondent headmaster information and Part $\mathrm{C}$ regarding teacher perceptions of headmaster leadership level in LINUS management in respondent schools involved in this study. The questionnaire questions in section $C$ require respondents to state their answer choices for each given item using a Likert scale. The scale of each questionnaire was based on a five-point Likert scale. Table 3 shows the mean rating scale of the five scores based on the mean score source used by Talib (1996).

In addition, the data analysis of this study used descriptive analysis to elaborate on the demographics of respondents and teachers in terms of gender, race, service duration and academic achievements. The statistics used are the frequency, percentage, mean and standard deviation to answer this research question. This study uses statistical analysis of inference to see the relationship 
Table 3. Interpretation Table for Mean Score (Talib, 1996).

\begin{tabular}{ccc}
\hline Mean Score & Level \\
\hline $1.00-1.80$ & Very Low \\
$1.81-2.60$ & Low \\
$2.61-3.40$ & Medium \\
$3.41-4.20$ & High \\
$4.21-5.00$ & Very High \\
\hline
\end{tabular}

between the gender of the headmaster and the duration of service to the leadership level of the LINUS management body. T-test statistics will be used where the hypothesis is used to test zero (Ho1, Ho2 and Ho3).

\section{Findings}

\section{Question 1: What is the teacher's perception of the level of leadership in LINUS management?}

Principals' leadership practice in primary schools in 'Zon Debak' is based on four dimensions in Burns (1978) and Bass's (1985) Transformational Leadership Theory of ideas influence, intellectual stimulation, inspirational motivation and individual judgment.

Table 4 shows that the dimension of the idea's influence is the highest with the score of mean $=4.47$ and standard deviation $=0.717$ followed by intellectual stimulus dimensions with score of mean $=4.46$ and standard deviation $=0.579$. Meanwhile inspirational motivation scored with mean $=4.40$ and standard deviation $=0.732$ while individual judgement ranked last with mean $=3.59$ and standard deviation $=0.779$. This shows that leadership based on the influence of a leader's ideas is very important in the management of LINUS in schools.

Question 2: What is the leadership level of LINUS management in primary schools in the 'Zon Debak' by gender?

Table 5 showed a high level of leadership by gender where 63 men (63\%) scores mean $=1.37$ (standard deviation $=0.845$ ) and 37 women with the score of mean $=4.95$ (standard deviation $=1.348)$. This shows that the mean score for male headmaster leadership levels was lower than for female head teachers.

Question 3: What's the difference in the leadership level of headmaster in primary schools under the management of LINUS in 'Zon Debak' over the service period?

Ho1; There was no significant difference in the level of headmaster leadership under the management of LINUS in primary schools in the 'Zon Debak' during the service period.

The t-test analysis in Table 6 shows that there was no significant difference between the mean of the leadership level according to the service period for both gender of headmasters $(\mathrm{F}=1.616 ; p>0.05)$. This shows that both genders have a similar level of leadership over the duration of service. This also indicates that this study failed to reject the null hypothesis of Hol. 
Table 4. Dimensions of headmaster leadership.

\begin{tabular}{ccccc}
\hline Qty & Dimensions & Mean & Standard Deviation & Level \\
\hline 1. & Ideas influences & 4.47 & 0.717 & Very high \\
2. & Intellectual stimulate & 4.46 & 0.579 & Very high \\
3. & Motivation inspiration & 4.40 & 0.732 & Very high \\
4. & Individual consideration & 3.59 & 0.779 & High \\
\hline
\end{tabular}

Table 5. Leadership level by gender.

\begin{tabular}{cccc}
\hline Gender & $(\mathrm{n})$ & Min Score & Std Deviation \\
\hline Male & 63 & 1.37 & 0.845 \\
Female & 37 & 1.28 & 1.348 \\
Total & 100 & & \\
\hline
\end{tabular}

Table 6. The t-test on leadership level of headmaster according to service period.

\begin{tabular}{ccccc}
\hline $\begin{array}{c}\text { Leadership Level of } \\
\begin{array}{c}\text { Headmaster according to } \\
\text { Service Period }\end{array}\end{array}$ & $\mathbf{n}$ & Mean Difference & $\mathbf{t}$ & Sig (2 end) \\
\hline & 100 & 3.44000 & 21.283 & 0.000 \\
\hline
\end{tabular}

\section{Discussion}

The results shown in the analyzed data from the study indicate that the headmasters have a good level of leadership as a school leader. This finding is supported by Azmi (2004) who says that leadership is the process of organizing the interaction of all members of the organization to achieve the common mission and goals. This is also supported by Mohd Izham (2011), stating that a leader particularly will always strive to influence staff to work towards achieving the goals. An administrator must communicate with employees of the organization and organization and motivate them to achieve that goal. These include staff development sessions, internal training, face-to-face discussions and bilateral dialogue.

The findings of the study also prove that the leadership of the headmaster resulted influence of good ideas that will be favoured by the staff under his leadership. This is supported by Rahmat (2006) who stated that leadership is the relationship between individuals and groups to share interests and goals together and to act in a manner that is influenced and felt by leaders. Leaders who have high levels of motivation in carrying out their duties and responsibilities provide opportunities for employees to come up with new ideas for greater success. This is supported by Mujik (2013) who argues that the dominant leadership style of headmaster is success oriented style, followed by participatory leadership style, supportive leadership style and direct leadership style. Clearly, there is a link between the leadership of the headmaster and the teacher's commitment to the school. The success rate of a school depends largely on the quality of the 
headmaster's emphasis on human capital such as optimum performance, high productivity, promoting creativity and innovation, and building a committed workforce (Oliff, 2006; Ross, 2006).

The analysis showed that there was no significant relationship between the level of headmaster leadership and service duration. This is a good indication for the State Department of Education and the District Education Office that both gender of headmasters are no different leaders as well as both being capable and competent as a head teacher. This is supported by Ahmad Sukri (2002) who argues that there is no difference in the ability of male and female workers in particular work that requires problem solving, motivation and analytical skills especially in the context of an educator. The term of service is not a hindrance for a person to perform their duties as a fair and respectable leader.

\section{Conclusion}

In conclusion, achieving the goals set by the NKRA, education depends largely on the cooperation of school leaders, educators and the local community. Success in the field of education involving management is to refine the education system to ensure that the quality of education is constantly enhanced to generate well-rounded leaders that will truly act as capable leaders. In fact, it may as well generate human capital that will become a better leader in the future.

\section{Acknowledgement}

This research was partially supported by grant received from the Faculty of Education, Universiti Kebangsaan Malaysia code GGP-2018-008 and PP-FPEND-2019

\section{Conflicts of Interest}

The authors declare no conflicts of interest regarding the publication of this paper.

\section{References}

Alias, B. S., Zainudin, Z. N., \& Nasri, N. M. (2018). Curriculum Management Competency of Malaysia's Principals. International Journal of Academic Research in Business and Social Sciences, 8, 1101-1107. https://doi.org/10.6007/IJARBSS/v8-i10/4830

Alimuddin, M. D. (2010). Ciri-Ciri Pengetua yang “Outstanding”. Selangor: Pendidik Widad Publications.

Aziz, S. F. A., \& Mat, S. C. (2017). Pengaruh Kepemimpinan Transformasi, Keberkesanan Latihan dan Kualiti Kehidupan Bekerja Terhadap Kualiti Perkhidmatan Guru di Malaysia (Influence of Transformational Leadership, Training Effectiveness and Quality of Work Life on Teachers' Service Quality in Malaysia). e-Bangi, 14, 1-14.

Bass, B. M. (1985). Leadership and Performance beyond Expectations. New York: Free Press.

Berawi, F. M. (2017). Metodologi Penyelidikan Panduan Menulis Tesis. ETM Prima Sdn. Bhd. 
Burns, J. M. (1978). Leadership. New York: Harper \& Row.

Cresswell, J. W. (2008). Educational Research (3rd ed.). Upper Saddle River, NJ: Pearson Education Ltd..

Edmonds, R. (1979). Effective Schools for the Urban Poor. Educational Leadership, 37, 15-24.

Fiedler, F. E. (1967). A Theory of Leadership Effectiveness. New York: McGraw-Hill

Hamzah, M., Izham, M., \& Shamsudin, S. (2017). Talent Management and Teacher Leadership Talent Development in High Performing School in Malaysia. International Journal of Educational Best Practices, 1, 19-35. https://doi.org/10.31258/ijebp.v1n1.p19-35

Harun, R. A., Ishak, N. M., Yusoff, N., \& Amat, S. (2017). Emotional Intelligence and Leadership Profiles among Students' Representative Council of Malaysian Public Universities. International Journal of Educational and Pedagogical Sciences, 11, 1334-1338.

Ibrahim, N., Ismail, A., Mohamed, N. K., Salim, S. S., \& Yusuf, M. H. (2015). Effect of Psychological Empowerment and Transformational Leadership on Organizational Commitment. Makara Hubs-Asia, 19, 75-86.

Khairuddin, M. (2011). Siri Pendidikan Guru Literasi Bahasa Melayu. Fajar Bakti.

Krejcie, R. V., \& Morgan, D. W. (1970). Determining Sample Size for Research Activities. Educational and Psychological Measurement, 30, 607-610. https://doi.org/10.1177/001316447003000308

Mujik, S. (2013). Persepsi guru terhadap gaya kepimpinan guru besar: satu kajian kes di sekolah rendah zon Dalit, Keningau. Doctoral Dissertation, Sabah, Malaysia: Universiti Malaysia Sabah.

Ryska, T. A. (2002). Leadership Styles and Occupational Stress among College Athletic Directors: The Moderating Effect of Program Goals. The Journal of Psychology, 136, 195-213. https://doi.org/10.1080/00223980209604150

Talib, G. H. (1996). Pembinaan Instrumen: Ceramah Kursus Penyelidikan Pendidikan (pp. 12-13). Anjuran Bahagian Pendidikan Guru, Kementerian Pendidikan Malaysia. 